\title{
RANGSANGAN PERKEMBANGAN OVARI UDANG PUTIH, Litopenaeus vannamei DENGAN PENYUNTIKAN ESTRADIOL-17 $\beta$
}

\author{
Tarsim*), Muhammad Zairin Junior ${ }^{* * *}$, dan Etty Riani**)
}

\begin{abstract}
ABSTRAK
Studi ini bertujuan untuk mengetahui pengaruh penyuntikan hormon estradiol-17 $\beta$ terhadap perkembangan ovari udang putih (Litopenaeus vannamei). Dosis estradiol$17 \beta$ yang digunakan adalah $0,05 \mu \mathrm{g} / \mathrm{g} ; 0,10 \mu \mathrm{g} / \mathrm{g} ; 0,25 \mu \mathrm{g} / \mathrm{g}$ bobot tubuh dan kontrol Hasil penelitian menunjukkan bahwa penyuntikan estradiol-17 $\beta$ berpengaruh terhadap perkembangan gonad. Indeks maturasi pada perlakuan dosis $0,10 \mu \mathrm{g} / \mathrm{g}$ and $0,25 \mu \mathrm{g} /$ $\mathrm{g}$ bobot tubuh lebih besar $(75,00 \%$ dan 66,67\%) dibanding kontrol. Peningkatan diameter oosit terlihat nyata pada TKG I dan II. Meskipun pada TKG III dan IV peningkatan oosit tidak terlihat nyata, tetapi proporsi oosit matang lebih besar. Hal ini menunjukkan bahwa pemberian estradiol-17 $\beta$ pada induk udang ablasi menghasilkan telur yang lebih cepat berkembang dibandingkan jika hanya menggunakan ablasi. Penyuntikan estradiol-17 $\beta$ sangat berpengaruh pada awal perkembangan gonad. Hal ini menunjukkan bahwa estradiol-17 $\beta$ berperan penting dalam merangsang endogenous vitelogenesis.
\end{abstract}

\section{ABSTRACT: Induction of ovarian development of white shrimp by estradiol- $17 \beta$ injection. By: Tarsim, Muhammad Zairin Junior, and Etty Riani}

The present study analyzed the effect of estradiol- $17 \beta$ injection on ovarian development of white shrimp, Litopenaeus vannamei. Estradiol- $17 \beta$ dose of $0.05 \mathrm{vg} / \mathrm{g}, 0.10 \mu \mathrm{g} / \mathrm{g}$, $0.25 \mu \mathrm{g} / \mathrm{g}$ body weight and the control was used, with 15 females broodstock of each. The result showed that ovarian development affected by estradiol-17 $\beta$ injection. Maturation index in dose of $0.10 \mu \mathrm{g} / \mathrm{g}$ and $0.25 \mu \mathrm{g} / \mathrm{g}$ body weight was $75.00 \%$ and $66.67 \%$ respectively and higher than that of control. Oocytes diameter increased significantly on stage I and stage II, although oocytes diameter in stage III and IV was no significant different but the proportion of mature oocyte higher than that of control. It suggested that estradiol-17 $\beta$ gave much more developed conditions in oocytes developmental stages and size, compared to control with unilateral eyestalk ablation only. The dominant effect is in early developmental stage of oocyte. It indicates that estradiol- $17 \beta$ is important to induction of endogenous vitellogenesis in white shrimp.

KEYWORDS: ovary, Litopenaeus vannamei, vitellogenesis, estradiol-17ß, oocyte

\section{PENDAHULUAN}

Teknologi reproduksi dalam pembenihan udang belum mengalami perkembangan yang signifikan. Mekanisme dan peranan hormon pada proses reproduksi udang belum banyak diketahui. Pada umumnya untuk mempercepat kematangan gonad induk udang digunakan teknik ablasi. Teknik ablasi cukup efektif dalam merangsang perkembangan gonad, tetapi penghilangan organ penghasil hormon akan mengganggu sistem endokrin dalam tubuh

\footnotetext{
Universitas Lampung, Lampung

*) Fakultas Perikanan dan IImu Kelautan, Institut Pertanian Bogor
} 
udang. Ablasi unilateral menyebabkan kerusakan permanen pada mata dan menurunkan $50 \%$ sintesis neurohormon oleh kelenjar sinus. Hal ini menyebabkan kemampuan udang untuk mengatur berbagai proses fisiologis dan tidak berjalan dengan baik (Huberman, 2000). Oleh sebab itu, perlu diupayakan teknik rangsangan pematangan gonad yang lebih efektif.

Teknik rangsangan hormonal dengan memberikan hormon-hormon perangsang perkembangan gonad telah banyak dilakukan pada ikan dan terbukti cukup efektif. Reproduksi udang dikendalikan oleh aktivitas neurohormon dan hormon-hormon reproduksi seperti GIH (gonado inhibiting hormone), GSH (gonado stimulating hormone), hormon penghambat kerja organ mandibular (mandibular organ inhibiting hormone-MOIH), dan MF (methyl farnesoate) (Chang, 1997; Charmantier et al., 1997). Selain itu, pada hemolim dan ovari beberapa spesies krustase juga ditemukan hormon steroid seperti

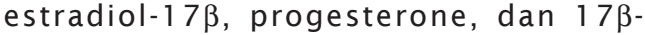
hydroxyprogesterone (Souty-Grosset, 1997; Summavielle et al., 2003; Okumura, 2004). Hormon-hormon tersebut merupakan hormon yang berperan penting dalam vitelogenesis ikan, sehingga keberadaannya dalam tubuh krustase khususnya udang diduga mempunyai peranan yang sama.

Percobaan pemberian hormon steroid (vertebrate-type steroid hormone) berpengaruh positif terhadap perkembangan gonad Penaeus japonicus (Yano, 1987), Macrobrachium rosenbergii (Ghosh \& Ray, 1992), Penaeus monodon (Ismail, 1991; Riani, 2001), Procrambarus clarkii (Rodriguez et al., 2002), dan Marsupenaeus japonicus (Summavielle et al., 2003). Salah satu hormon steroid yang berperan penting dalam perkembangan gonad khususnya vertebrata adalah estradiol-17 $\beta$. Pada udang putih, peran dan fungsi hormon estradiol-17 3 dalam perkembangan gonad belum banyak diketahui. Beberapa penelitian yang telah dilakukan menunjukkan hasil yang bervariasi. Berdasarkan hal tersebut maka perlu dilakukan uji dan kajian lebih lanjut mengenai peran hormon estradiol-17 $\beta$ pada perkembangan gonad udang khususnya udang putih. Pemberian hormon steroid khususnya estradiol-17 $\beta$ pada udang putih diharapkan berpengaruh positif terhadap perkembangan gonad sehingga dapat digunakan sebagai teknik alternatif pematangan gonad pada udang.

\section{BAHAN DAN METODE}

\section{Waktu dan Tempat}

Percobaan dilaksanakan pada bulan April hingga bulan Juni 2006 di Balai Budidaya Air Payau (BBAP) Situbondo, Jawa Timur. Pembuatan preparat dan analisis histologi gonad dilakukan di Laboratorium Penyakit Ikan, Jurusan Budidaya Perairan, FPIK-IPB.

\section{Hewan dan Bahan Uji}

Hewan uji adalah induk udang putih yang telah berumur 9 bulan dan berukuran $38 \pm 2 \mathrm{~g}$ yang merupakan keturunan pertama dari persilangan asal Hawai dan Florida. Hormon yang digunakan sebagai bahan uji adalah estradiol-17 $\beta$ produksi Argent Co. Ltd.

\section{Pemberian Perlakuan}

Metode yang digunakan dalam percobaan ini adalah metode eksperimental. Percobaan ini menggunakan 3 perlakuan tingkat dosis hormon estradiol-17 $\beta$. Adapun dosis yang digunakan adalah $0,05 \mathrm{vg} / \mathrm{g} ; 0,10 \mu \mathrm{g} / \mathrm{g} ; 0,25$ $\mu \mathrm{g} / \mathrm{g}$ bobot tubuh. Masing-masing perlakuan terdiri atas 15 ekor induk betina berukuran 38 $\pm 2 \mathrm{~g}$, sebagai pembanding dilakukan uji tanpa perlakuan (kontrol). Pemberian estradiol dilakukan dengan menyuntikkannya melalui pangkal kaki jalan kelima menggunakan Syringe tuberculline $(1 \mathrm{~mL})$. Sebelum disuntikkan, estradiol terlebih dahulu dilarutkan dalam minyak jagung. Volume penyuntikan adalah $100 \mu \mathrm{L} /$ induk dengan konsentrasi sesuai disain perlakuan. Penyuntikan dilakukan 3 hari setelah ablasi.

\section{Pemeliharaan Induk}

Induk yang telah diberi perlakuan dan kontrol dipelihara dalam bak beton berwarna hitam berukuran $2 \mathrm{~m} \times 2 \mathrm{~m} \times 1 \mathrm{~m}$. Air pemeliharaan berasal dari laut yang telah di saring dengan salinitas $32-33$ ppt dan temperatur $27^{\circ} \mathrm{C}-28^{\circ} \mathrm{C}$. Air mengalir kontinyu dengan debit $5 \mathrm{~L} /$ menit. Selama pemeliharaan induk diberi pakan 5 kali perhari sebesar 15\%$20 \%$ biomass dengan komposisi $40 \%$ cumi, $40 \%$ kerang, $15 \%$ polychaeta, dan 5\% pelet. Agar kondisi kualitas air dalam bak tetap baik, air diaerasi dan kotoran yang ada di dasar bak dibersihkan setiap hari dengan cara disipon. 


\section{Penentuan Tingkat Kematangan Gonad}

Tingkat kematangan gonad secara morfologi didasarkan pada perubahan bentuk dan warna ovari diamati setiap hari. Kriteria tingkat kematangan berdasarkan Yano (1988) dalam Vaca \& Alfaro (2000).

Selain berdasarkan morfologi, tingkat kematangan gonad juga ditentukan berdasarkan analisis histologi gonad yang dilakukan pada akhir perlakuan. Gonad diambil dari tubuh induk dan ditimbang. Sebagian gonad difiksasi dalam larutan Davidson dan sebagian ditentukan diameter oositnya. Gonad yang telah difiksasi didehidrasi dengan etanol dan dijernihkan dengan kloroform. Contoh gonad kemudian diembeding dalam campuran parafin-paraplas, selanjutnya dipotong menggunakan mikrotom dengan ketebalan 5 ìm dan diberi warna dengan pewarna hematoxylin-eosin. Preparat histologi diamati dengan mikroskop cahaya untuk ditentukan sebaran oositnya pada setiap tahap perkembangan gonad. Adapun kriteria tahap perkembangan oosit pada gonad udang putih didasarkan menurut Medina et al. (1996).

\section{Penentuan Indeks Maturasi (Maturation Index) (MI)}

Indeks maturasi ditentukan berdasarkan persamaan berikut (Alfaro et al., 2004):

$$
\mathrm{MI}(\%)=\frac{\sum \text { individu TKG III dan IV }}{\text { Jumlah total individu }} \times 100
$$

Penentuan indeks maturasi dilakukan 6 hari setelah penyuntikan. Pengamatan dilakukan setiap hari hingga hari ke-12.

\section{Pengukuran Diameter Oosit}

Gonad yang mengandung oosit dimasukkan kedalam larutan formaldehide 5\% selama dua hari untuk memperkuat dan menstabilkan oosit serta memisahkan oosit satu sama lainnya. Pengukuran diameter oosit untuk setiap perkembangan gonad dilakukan pada bagian depan (cuping anterior), tengah (cuping abdominal), dan belakang (cuping posterior) ovari. Sejumlah 100 butir telur diambil secara acak pada petridisk untuk selanjutnya diukur diameternya dengan mikroskop binokuler yang dilengkapi dengan mikrometer. Pengukuran tersebut dilakukan pada lima bidang pandang dengan perbesaran
100 kali. Hasil pengukuran ditampilkan dalam bentuk sebaran frekuensi.

\section{Analisis Data}

Analisis data menggunakan program Minitab versi 14 . Uji tingkat perbedaan, kecepatan matang gonad, diameter, dan sebaran oosit dilakukan dengan analisis satu arah antar perlakuan (ANOVA). Untuk data yang berbeda nyata dilakukan uji lanjut dengan menggunakan uji Tukey pada tingkat kepercayaan 95\%.

\section{HASIL DAN BAHASAN}

\section{Hasil}

\section{Perkembangan gonad}

Pada studi ini, induk yang telah diablasi dan diberi hormon estradiol-17 $\beta$ maupun yang tidak diberi hormon mengalami perkembangan gonad. Hal ini ditunjukkan dengan adanya peningkatan indeks maturasi selama pemeliharaan (Gambar 1).

Kematangan gonad induk mulai terjadi pada hari ke-7 dan 8 serta mencapai maksimum pada hari ke-11 dan 12. Persentase maksimum induk yang mencapai TKG III dan IV (ditunjukkan dengan nilai indeks maturasi) pada kontrol (dosis $0,00 \mu \mathrm{g} / \mathrm{g}$ bobot tubuh) adalah $37,5 \%$; sedangkan pada penyuntikan estradiol- $17 \beta$ dosis $0,05 \mu \mathrm{g} / \mathrm{g} ; 0,10 \mu \mathrm{g} / \mathrm{g}$; dan $0,25 \mu \mathrm{g} / \mathrm{g}$ adalah $44,44 \% ; 75,00 \%$; dan $66.67 \%$. Dibandingkan dengan kontrol, nilai indeks maturasi pada perlakuan dosis $0,10 \mathrm{ig} / \mathrm{g}$ dan $0,25 \mu \mathrm{g} / \mathrm{g}$ relatif lebih tinggi $(\mathrm{P}<0,01)$; sedangkan pada perlakuan dosis $0,05 \mu \mathrm{g} / \mathrm{g}$ tidak berbeda $(P>0,05)$.

Pada grafik kecepatan perkembangan gonad (Gambar 2), penyuntikan dosis $0,10 \mu \mathrm{g} / \mathrm{g}$ dan $0,25 \mu \mathrm{g} / \mathrm{g}$ bobot tubuh memberikan respons waktu yang diperlukan untuk mencapai TKG I dan II lebih cepat dibandingkan dengan kontrol $(P<0,05)$, sedangkan pada dosis $0,05 \mu \mathrm{g} / \mathrm{g}$ tidak berbeda nyata $(P>0,05)$. Untuk mencapai TKG I pada dosis $0,10 \mu \mathrm{g} / \mathrm{g}$ dan 0,25 $\mu \mathrm{g} / \mathrm{g}$ diperlukan waktu 4 dan 5 hari, sedangkan pada kontrol dan dosis $0,05 \mu \mathrm{g} / \mathrm{g}$ diperlukan waktu 8 hari. Untuk mencapai TKG II diperlukan waktu $6-7$ hari pada dosis $0,10 \mu \mathrm{g} / \mathrm{g}$ dan 0,25 $\mu \mathrm{g} / \mathrm{g}$, sedangkan pada kontrol dan dosis 0,05 $\mu \mathrm{g} / \mathrm{g}$ adalah $10-11$ hari. Pada semua perlakuan, tidak terdapat perbedaan waktu yang nyata untuk mencapai TKG III dan IV $(P>0,05)$. Pada dosis $0,10 \mu \mathrm{g} / \mathrm{g}$ dan $0,25 \mu \mathrm{g} / \mathrm{g}$, 


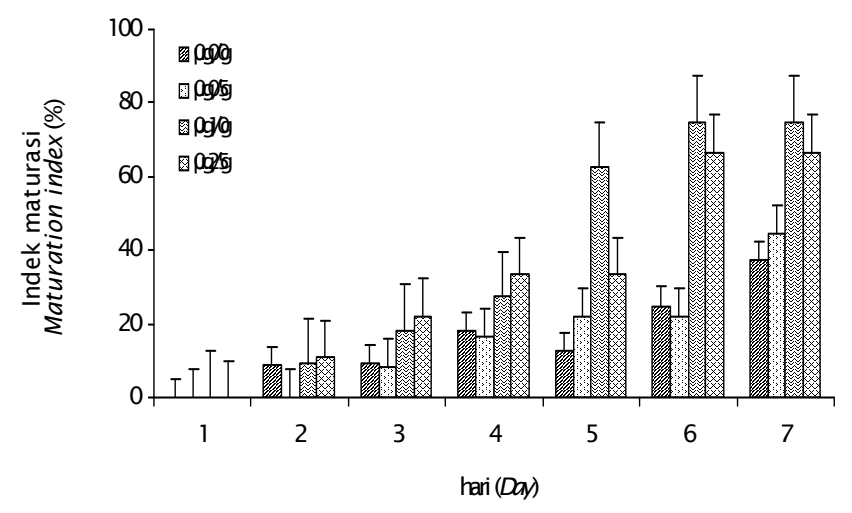

Gambar 1. Indeks maturasi pada berbagai perlakuan dosis hormon estradiol-17 $\beta$

Figure 1. Maturation Index on different dose of estradiol-17 $\beta$

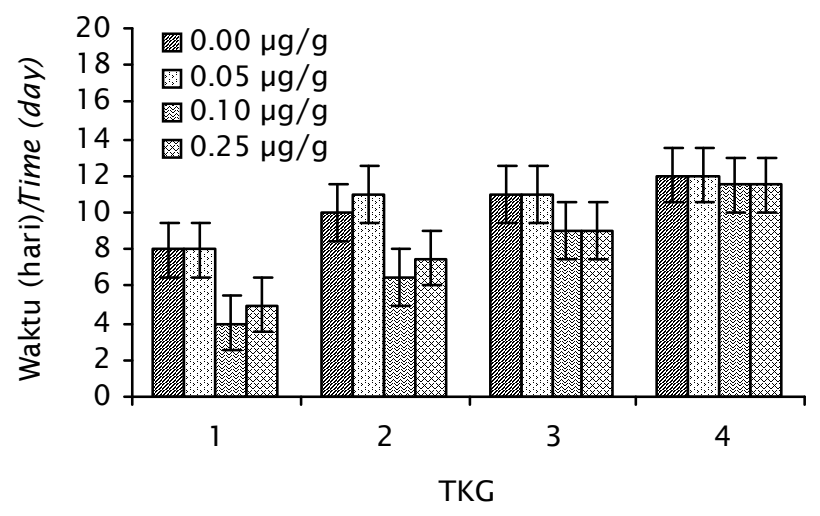

Gambar 2. Kecepatan perkembangan gonad pada berbagai perlakuan dosis estradiol-17 73

Figure 2. Gonad development rate on different dose of estradiol-17 $\beta$

TKG III dicapai dalam waktu 9 hari sedangkan pada kontrol dan dosis $0,05 \mu \mathrm{g} / \mathrm{g}$ diperlukan waktu 11 hari. Perbedaan waktu ini semakin mengecil saat mencapai TKG IV. Waktu yang perlukan untuk mencapai TKG IV pada kontrol dan dosis $0,05 \mu \mathrm{g} / \mathrm{g}$ adalah 12 hari sedangkan pada dosis $0,10 \mu \mathrm{g} / \mathrm{g}$ dan $0,25 \mu \mathrm{g} / \mathrm{g}$ diperlukan waktu 11,5 hari.

Analisis histologi gonad (Gambar 3) menunjukkan bahwa pada TKG I, di dalam gonad terdapat bakal sel telur (oogonia) dan sel telur tahap pravitelogenesis dengan diameter berkisar 19,2-57,6 $\mu \mathrm{m}$. Pada tahap pravitelogenesis, sel telur (oosit) telah tampak nukleus dan beberapa nukleolus dalam nukleoplasma. Nukleolus umumnya berada di bagian tepi nukleus.
Pada TKG II, selain terdapat oosit pravitelogenesis juga terdapat oosit tahap awal vitelogenesis. Pada tahap ini ukuran sitoplasma jauh lebih besar dibandingkan dengan tahap sebelumnya. Diameter oosit berkisar antara 76,6-96,0 $\mu \mathrm{m}$, tetapi frekuensi terbanyak pada diameter $86,8 \mu \mathrm{m}$. Sitoplasma mulai terisi oleh butiran-butiran kuning telur sehingga tampak terjadi perubahan warna oosit. Pemberian hormon estradiol-17 $\beta$ dengan dosis $0,10 \mu \mathrm{g} / \mathrm{g}$ dan $0,25 \mu \mathrm{g} / \mathrm{g}$ bobot tubuh memberikan respon peningkatan proporsi jumlah tipe oosit awal vitelogenesis yang lebih besar dibanding kontrol. Proporsi jumlah tipe oosit awal vitelogenesis pada kontrol adalah 33\%, sedangkan pada dosis 0,05 

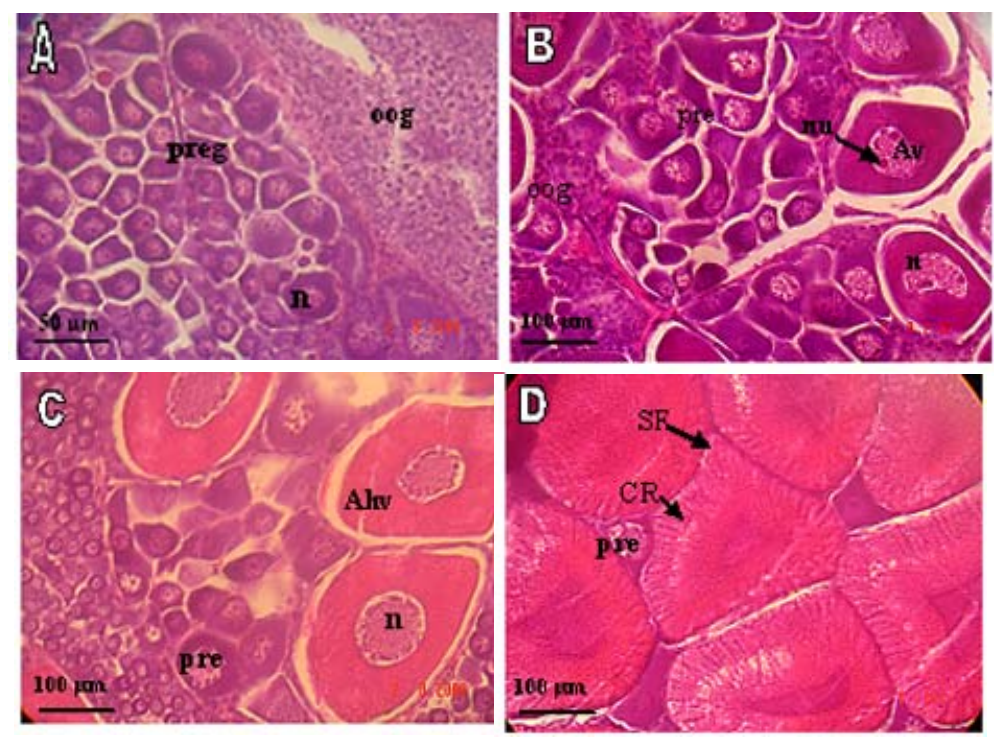

Gambar 3. Tahap perkembangan gonad udang putih (L. vannamei), histologi dilakukan dengan perwarnaan hematoxilin-eosin. A. TKG I, B. TKG II, C. TKG III, dan D. TKG IV. pre (previtelogenesis), oog (oogonia), Av (awal vitelogenesis), Ahv (akhir vitelogenesis), $\mathrm{n}$ (nukleus), nu (nukleolus) SF (sel folikel), CR (cortical rods)

Figure 3. Gonad developmental stages of white shrimp (L. vannamei), the hematoxilineosin was used on gonad histology. A. Stage I, B. Stage II, C. Stage III, dan D. Stage IV. pre (previtellogenesis), oog (oogonia), Av (early vitellogenesis), Ahv (late vitellogenesis), n (nucleus), nu (nucleolus) SF (follikel cell), CR (cortical rods)Gambar

$\mu \mathrm{g} / \mathrm{g} ; 0,10 \mu \mathrm{g} / \mathrm{g}$; dan $0,25 \mu \mathrm{g} / \mathrm{g}$ adalah berturutturut 39\%, 53\%, dan 48\% (Tabel 1).

Pada TKG III terdapat tiga tipe telur yaitu pravitelogenesis, awal vitelogenesis, dan akhir vitelogenesis. Pada fase akhir vitelogenesis, nukleus masih tampak tetapi nukleolus sudah tidak tampak lagi. Selain itu, terlihat butiranbutiran besar protein yang merupakan gabungan dari butiran-butiran protein kecil yang menyebar di dalam sitoplasma. Diameter oosit fase ini berkisar antara 105,6-153,0 $\mu \mathrm{m}$. Perbedaan respon perlakuan terjadi pada proporsi jumlah oosit tipe akhir vitelogenesis. Proporsi oosit tipe akhir vitelogenesis pada kontrol dan perlakuan estradiol dosis $0,05 \mu \mathrm{g} /$ g adalah $23 \%$, sedangkan pada dosis $0,10 \mu \mathrm{g} /$ $\mathrm{g}$ dan $0,25 \mu \mathrm{g} / \mathrm{g}$ masing-masing adalah $37 \%$ dan $35 \%$.

Tipe oosit yang terdapat pada TKG IV yaitu pravitelogenesis, akhir vitelogenesis dan oosit matang dan hanya sebagian kecil yang masih dalam tahap awal vitelogenesis. Pada oosit yang matang, butiran-butiran besar pro- tein di dalam sitoplasma semakin besar dan banyak. Oosit matang dicirikan dengan munculnya protein cortical rods (CRs). Selain itu, inti mulai melebur dan beberapa sudah tidak tampak lagi. Diameter oosit berkisar antara 201,6-211,2 $\mu \mathrm{m}$. Pemberian estradiol$17 \beta$ berpengaruh terhadap peningkatan jumlah oosit matang. Proporsi oosit matang pada pemberian estradiol- $17 \beta$ dosis $0,05 \mu \mathrm{g} /$ g; dosis $0,10 \mu \mathrm{g} / \mathrm{g}$; dan $0,25 \mu \mathrm{g} / \mathrm{g}$ masingmasing adalah $22 \%, 30 \%$, dan $26 \%$, sedangkan pada kontrol sebesar 20\%. Kecenderungan penurunan proporsi oosit matang pada perlakuan $0,25 \mu \mathrm{g} / \mathrm{g}$ diduga karena berdasarkan pengamatan histologi sebagian oosit matang telah mengalami degerasi sehingga presentasinya menurun.

\section{Diameter oosit}

Berdasarkan uji normalitas KolmogorovSmirmov, diameter oosit pada semua perlakuan menyebar normal $(\mathrm{P}<0,05)$ (Gambar 4). Kisaran diameter oosit setiap tahap perkembangan gonad pada semua perlakuan relatif sama. Hal 


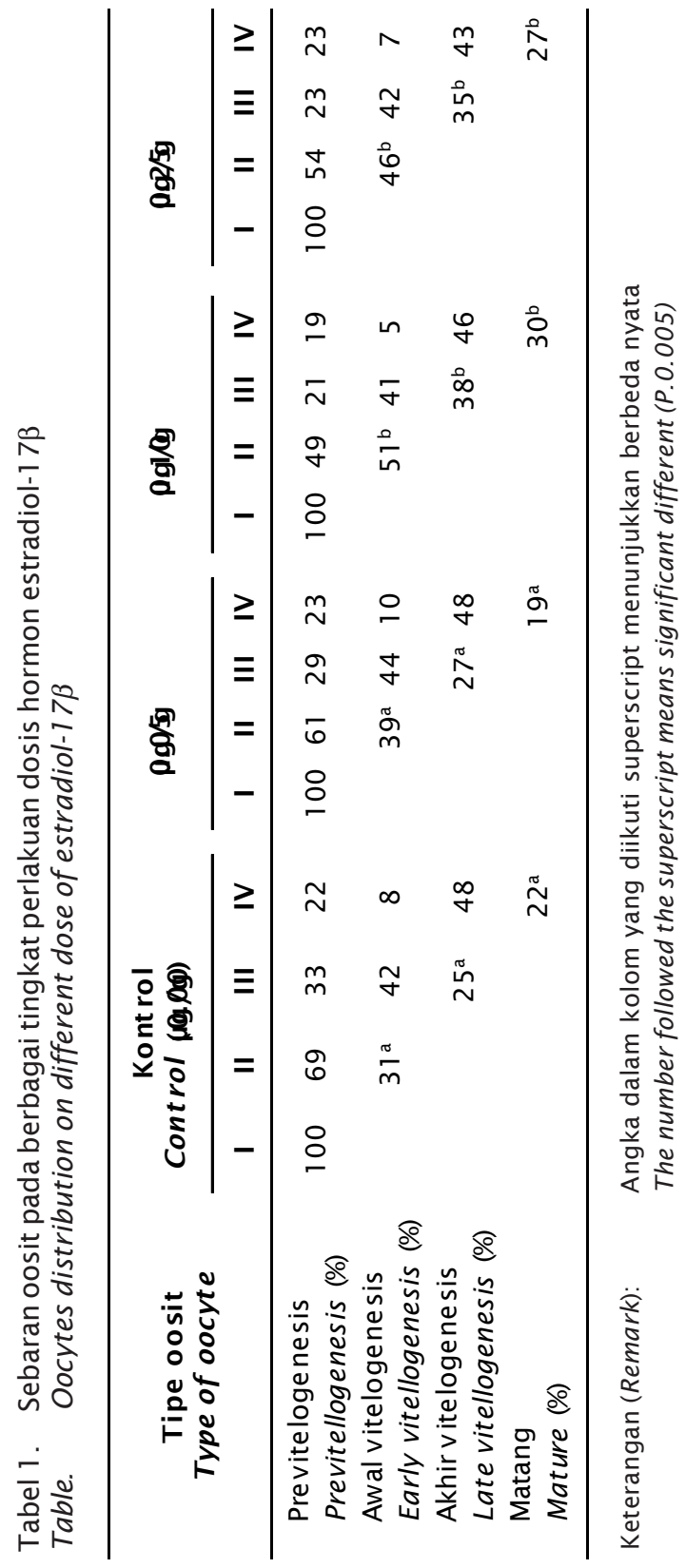



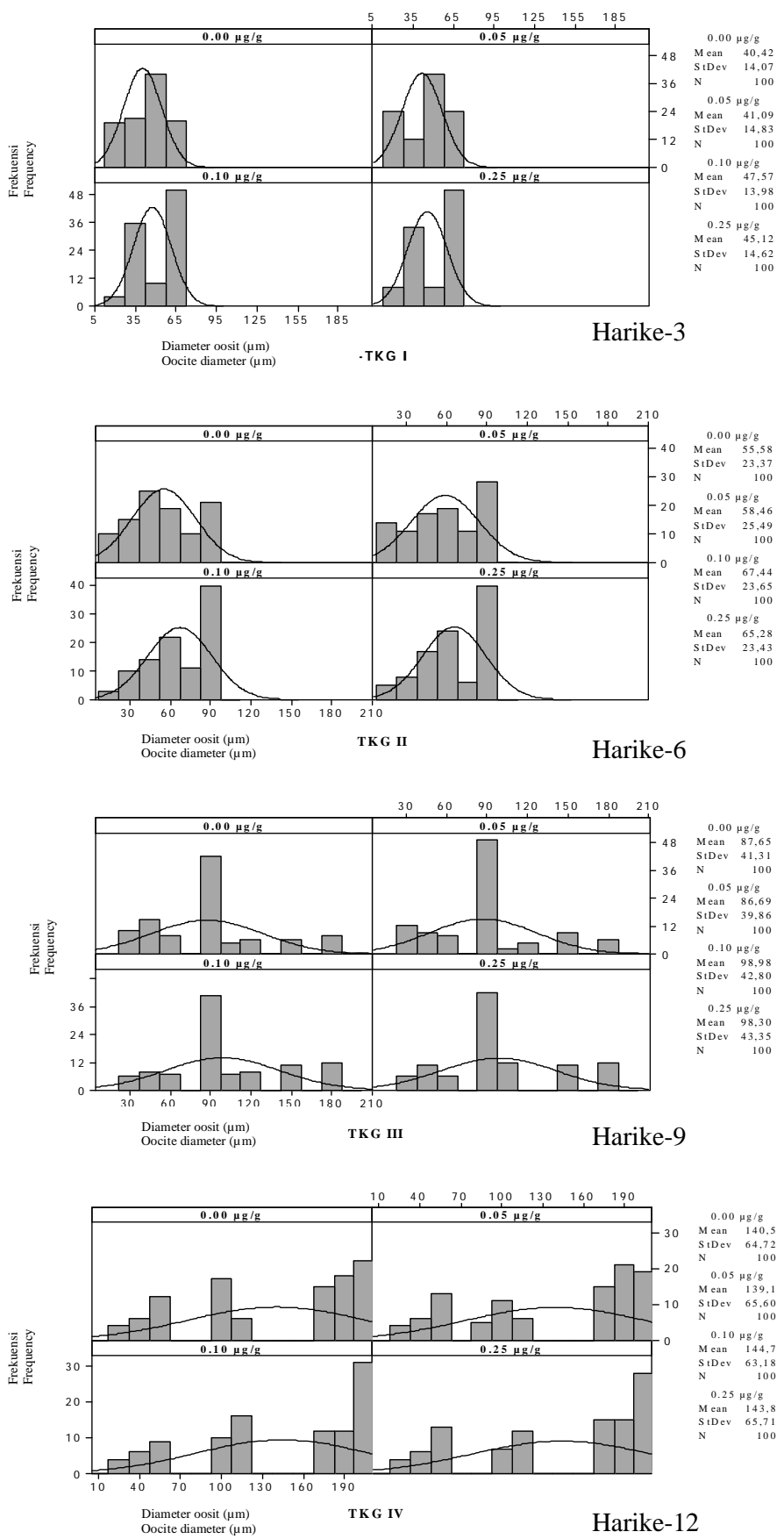

Gambar 4. Sebaran frekuensi diameter oosit pada TKG dan waktu (t) tertentu

Figure 4. Frequency distribution of oocytes diameter in the same time and gonad development stage 
ini ditunjukkan dengan rentang kurva yang tidak jauh berbeda. Adanya perbedaan pengaruh perlakuan terhadap ukuran oosit terlihat cukup nyata pada TKG I dan II. Hal ini ditunjukkan dengan puncak kurva sebaran normal diameter oosit yang lebih bergeser ke kanan. Selain itu, frekuensi diameter oosit $>60$ $\mu \mathrm{m}$ pada perlakuan $0,10 \mu \mathrm{g} / \mathrm{g}$ dan $0,25 \mu \mathrm{g} / \mathrm{g}$ lebih tinggi dibanding kontrol dan perlakuan dosis $0,05 \mu \mathrm{g} / \mathrm{g}$ bobot tubuh. Rata-rata diameter oosit TKG I pada control; perlakuan $0,05 \mu \mathrm{g} / \mathrm{g} ; 0,10 \mu \mathrm{g} / \mathrm{g}$; dan $0,25 \mu \mathrm{g} / \mathrm{g}$ masingmasing adalah $39,45 \mu \mathrm{m} ; 38,88 \mu \mathrm{m} ; 45,50 \mu \mathrm{m}$; dan $46,70 \mu \mathrm{m}$. Perlakuan dosis $0,10 \mu \mathrm{g} / \mathrm{g}$ dan $0,25 \mu \mathrm{g} / \mathrm{g}$ memberikan peningkatan diameter telur yang lebih besar $(P<0,01)$. Hal yang sama juga terjadi saat TKG II, rata-rata diameter oosit pada perlakuan dosis $0,10 \mu \mathrm{g} / \mathrm{g}$ dan $0,25 \mu \mathrm{g} /$ $\mathrm{g}$ relatif lebih besar $(69,64 \mu \mathrm{m}$ dan $65,86 \mu \mathrm{m})$ dibanding dengan kontrol dan perlakuan dosis $0,05 \mu \mathrm{g} / \mathrm{g}$ bobot tubuh $(57,41 \mu \mathrm{m}$ dan 56,64 $\mu \mathrm{m})$. Pada TKG III, perbedaan rata-rata diameter oosit menurun tetapi masih cukup siknifikan. Pada TKG IV, rata-rata diameter oosit di semua perlakuan tidak berbeda nyata, tetapi frekuensi diameter oosit $>200 \mu \mathrm{m}$ pada perlakuan dosis $0,10 \mu \mathrm{g} / \mathrm{g}$ dan $0,25 \mu \mathrm{g} / \mathrm{g}$ lebih tinggi dibanding kontrol dan perlakuan dosis $0,05 \mu \mathrm{g} / \mathrm{g}$.

\section{Bahasan}

Pemberian estradiol-17 $\beta$ pada induk udang putih yang telah mengalami ablasi memberikan respon positif terhadap perkembangan gonad. Secara umum jika dibandingkan dengan kontrol, pemberian estradiol-17 $\beta$ pada dosis $0,10 \mu \mathrm{g} / \mathrm{g}$ dan $0,25 \mu \mathrm{g} / \mathrm{g}$ bobot tubuh menyebabkan perkembangan gonad lebih cepat. Hal ini terlihat dari indeks kematangan yang lebih tinggi pada akhir pengamatan. Estradiol larut dalam lemak dan dapat langsung masuk ke dalam sel serta berikatan dengan reseptornya dalam inti. Kompleks steroid dan reseptor tersebut menyebabkan peningkatan ekspresi gen pengendali sintesis vitelogenin (Tiu \& Chan, 2005), kemudian meningkatkan aktivitas RNA dan pembentukan mRNA yang selanjutnya meningkatkan sintesis protein. Berdasarkan pengamatan Ghosh \& Ray (1992), secara in vitro pemberian hormon estradiol$17 \beta$ mempercepat sintesis energi melalui transpor ion dan pengaktifan metabolisme hepatopankreas. Meningkatnya metabolisme hepatopankreas diduga akan mempercepat sintesis vitelogenin kemudian ditransfer ke oosit. Pada udang penaeid, estradiol akan merangsang sel-sel folikel ovari untuk melakukan vitelogenesis. Selain itu, estradiol diduga juga memberikan feedback positif terhadap sintesis serotonin yang akan merangsang sekresi gonado stimulating hormone ganglion toraks (Yano, 1998).

Berdasarkan analisis lebih lanjut pada kecepatan perkembangan gonad tiap individu menunjukkan bahwa pengaruh penyuntikan estradiol-17 3 tampak berbeda sangat nyata pada awal perkembangan gonad yaitu pada TKG I dan II. Hal ini juga tampak pada perbedaan diameter oosit yang signifikan antar perlakuan. Ini menunjukkan bahwa estradiol berperan penting pada tahap awal vitelogenesis (previtellogenesis). Pada penelitian sebelumnya oleh Tsukimura \& Kanemoto (1991), pemberian hormon steroid (17- $\alpha$-Hydroxyprogesterone) terhadap oosit $L$. vannamei secara in vitro mampu merangsang terjadinya endogenous vitellogenesis. Hormon 17- $\beta$-Hydroxyprogesterone merupakan prekursor testosteron dan dengan bantuan enzim aromatase akan dikonversi menjadi estradiol. Adanya aktifitas 17 $\beta$-HSD (Hydroxy Steroid Dehydogenase) dan aromatase pada ovari dan hepatopankreas udang dikemukakan oleh Summavielle et al. (2003). Pada awal perkembangan gonad, estradiol akan merangsang sel folikel ovari dalam sintesis prekursor $\mathrm{Vg}$ yang akan digunakan dalam proses vitelogenesis (Yano, 1998). Protein tersebut diduga merupakan komponen protein cortical rods (CRs) yang muncul pada akhir vitelogenesis. Yamano et al. (2004) menyatakan bahwa protein CRs disintesis pada awal perkembangan ovari, meskipun pembentukan strukturnya terjadi pada oosit matang.

Tidak terlihatnya perbedaan kecepatan perkembangan gonad pada TKG III dan IV diduga terkait dengan menurunnya konsentrasi estradiol dalam tubuh induk akibat metabolisme. Turunnya kandungan estradiol dalam hemolim diduga menyebabkan kerja hormon terhadap organ target tidak optimal. Baclaski (2001) menyatakan bahwa hormon yang berperan besar pada tahap vitelogenesis sekunder (TKG III dan IV) L. vannamei adalah methyl farnesotae (MF). Kandungan MF pada saat vitelogenesis sekunder meningkat pesat, hal ini diduga menyebabkan respons pemberian estradiol menjadi tidak terlihat. Meskipun pada TKG tidak terlihat adanya perbedaan waktu perkembangan gonad, tetapi ukuran oosit oosit pada perlakuan $0,10 \mu \mathrm{g} / \mathrm{g}$ 
dan $0,25 \mu \mathrm{g} / \mathrm{g}$ relatif lebih besar dibanding kontrol dan perlakuan $0,05 \mu \mathrm{g} / \mathrm{g}$. Hal ini menunjukkan bahwa estradiol-17 $\beta$ juga berperan dalam vitelogenesis sekunder meskipun peranannya tidak sebesar saat awal vitelogenesis. Pemberian estradiol-17 $\beta$ pada dosis $0,10 \mu \mathrm{g} / \mathrm{g}$ dan $0,25 \mu \mathrm{g} / \mathrm{g}$ bobot tubuh juga mampu meningkatkan persentase oosit matang pada TKG IV (Tabel 2). Peningkatan persentase ini diduga terkait dengan kesiapan oosit saat memasuki tahap vitelogenesis sekunder (exogenous vitellogenesis). Terjadinya vitelogenesis primer (endogenous vitellogenesis) akibat rangsangan estradiol meningkatkan persentase oosit yang siap memasuki tahap vitelogenesis sekunder. Terjadinya vitelogenesis primer akan meningkatkan komponen protein CRs yang merupakan penciri oosit matang (Yamano et al., 2004). Atas dasar tersebut diduga bahwa estradiol merangsang ovari untuk mensintesis CRs. Tidak adanya perbedaan waktu dan ukuran oosit pada TKG IV disebabkan pada tahapan ini pertambahan diameter oosit mulai menurun, yang terjadi adalah proses pembentukkan struktur cortical rods yang diperlukan saat pemijahan.

Pola perkembangan sel telur pada kelompok induk antar perlakuan relatif sama. Pada setiap tahap perkembangan gonad terdapat sel telur dengan beberapa fase perkembangan yang berbeda. Ini menunjukkan bahwa perkembangan oosit L. vannamei berlangsung kontinyu. Hal yang sama juga terjadi pada udang windu (Ismail, 1991). Hasil ini dikuatkan pernyataan Quackenbush (2001) bahwa pada udang penaeid, proses oogenesis terjadi kontinyu sepanjang hidupnya.

\section{KESIMPULAN}

Berdasarkan hasil penelitian dapat disimpulkan bahwa pada dosis $0,10 \mu \mathrm{g} / \mathrm{g}$ bobot tubuh, pemberian estradiol-17 $\beta$ pada induk udang putih ablasi cukup efektif dalam merangsang perkembangan gonad. Hal ini ditunjukkan dengan adanya peningkatan diameter oosit yang lebih cepat. Pemberian estradiol-17 3 dan ablasi mata memberikan efek sinergis pada awal perkembangan gonad induk betina udang putih, Litopenaeus vannamei. Peningkatan diameter oosit sangat nyata pada awal vitelogenesis. Hal ini menunjukkan bahwa estradiol-17 $\beta$ berperan penting dalam merangsang endogenous vitelogenesis. Pada akhir vitelogenesis, pemberian estradiol-17 $\beta$ dapat meningkatkan jumlah telur yang siap dipijahkan, hal ini terlihat pada proporsi telur matang (oosit CRs) yang lebih tinggi dibanding kontrol.

\section{UCAPAN TERIMA KASIH}

Ucapan terima kasih yang sebesarbesarnya kepada Bapak Ir. Slamet Subiyakto, M.S. selaku Kepala Balai Budidaya Air Payau Situbondo dan kepada semua fihak yang telah membantu terselesainya penelitian ini.

\section{DAFTAR PUSTAKA}

Alfaro, J., G. Zu 'n iga., and J. Komen. 2004. Induction of ovarian maturation and spawning by combined treatment of serotonin and a dopamine antagonist, spiperone in Litopenaeus stylirostris and Litopenaeus vannamei. Aquaculture. 236: $511-522$.

Baclaski, B.J. 2001. Crustacean reproductive hormonal control and the role of methyl farnesoate. University of Connecticut. Molecular and Cell Biology. USA. 7 pp.

Chang, E.S. 1997. Chemistry of crustacean hormones that regulate growth and reproduction. In: Fingerman, M., R. Nagabhushanam., M. Thompson. Editors. Recent advances in marine biotechnology. Vol. 1. Endocrinology and reproduction. Science Publisher, Inc. USA. (I): 163-178.

Charmantier, G., Charmantier-Daures M., and Van Herp F. 1997. Hormonal regulation of growth and reproduction in crustaceans. In: Fingerman, M., R. Nagabhushanam., M. Thompson. (Eds). Recent advances in marine biotechnology. Endocrinology and reproduction. Science Publisher, Inc. USA. (I): 109-162.

Ghosh, D. and A.K. Ray. 1992. Subcellular actions of estradiol-17 $\beta$ in a freshwater prawn, Macrobrachium rosenbergii. General and Comparative Endocrinology. 90: 274-281.

Huberman, A. 2000. Shrimp endocrinology. A review. Aquaculture. 191: 191-208.

Ismail, A. 1991. Pengaruh Rangsangan Hormon terhadap Perkembangan Gonad Individu Betina dan Kualitas Telur Udang Windu (Penaeus monodon). Disertasi. Program Pascasarjana. Intstitut Pertanian Bogor. 125 pp.

Medina, A., Y. Vila, G. Mourente, and A. Rodriguez. 1996. A Comparative study of the ovarian development in wild and pondreared shrimp, Penaeus kerathurus (Forskal, 1775). Aquaculture. 148: 63-75. 
Okumura, T. 2004. Review: Perpective on hormonal manipulation of shrimp reproduction. JARQ. 38: 49-54.

Quackenbush, L.S. 2001. Yolk synthesis in the marine shrimp, Penaeus vannamei. American Zoologist. 41: 465-476.

Riani, E. 2001. Peningkatan Dayaguna Induk Udang Windu (Penaeus monodon Fab.) Afkir Melalui Pemberian Dopamin serta Modifikasinya dengan Estradiol dan Vitamin. Disertasi. Program Pascasarjana. Intstitut Pertanian Bogor. 95 pp.

Rodriguez, E.M., L.S.L. Greco, D.A. Medesani, H. Laufer, and M. Fingerman. 2002. Effect of methyl farnesoate, alone and in combination with other hormones, on ovarian growth of the red swamp crayfish, Procrambarus clarkii, during vitellogenesis. General and Comparative Endocrinology. 225: 34-40.

Souty-Grosset, C. 1997. Vitellogenin synthesis in marine invertebrate. In: Fingerman, M., R. Nagabhushanam, M. Thompson. (Eds.). Recent advances in marine biotechnology. Endocrinology and reproduction. Science Publisher, Inc. USA. (I): 203-248.

Summavielle, T., P.R.R. Monteiro, M.A. ReisHendriquez, and J. Coimbra. 2003. In vitro metabolism of steroid hormones by ovary and hepatopancreas of the crustacean penaeid shrimp Marsupenaeus japonicus. Scientia Marina. 67: 299-306.

Tiu, S.H.K. and S.M. Chan. 2005. Stimulation of shrimp vitellogenin gene expression in vitro: Effects of 20-hydroxyecdysone, farnesoic acid and other hormones. The $15^{\text {th }}$ International Congress of Comparative Endocrinology, May 23-28 2005, USA. p. 48-53.

Tsukimura, B. and F.I. Kanemoto. 1991. In vitro stimulation of oocytes by presumptive mandibular organ secretions in the shrimp, Penaeus vannamei. Aquaculture. 92: 5966.

Vaca, A.A. and J. Alfaro. 2000. Ovarian maturation and spawning in the white shrimp, Penaeus vannamei, by serotonin injection. Aquaculture. 182: 373-385.

Yamano, K., G. Qiu, and T. Unuma. 2004. Molecular cloning and ovarian expression profiles of thrombospondin, a major component of cortical rods in mature oocytes of penaeid shrimp, Marsupenaeus japonicus. Biology of Reproduction. 70: $1,670-1,678$.

Yano, I. 1987. Effect of 17-hydroxyprogesterone on vitellogenin secretion in kuruma prawn, Penaeus japonicus. Aquaculture. 61: 49-51.

Yano, I. 1998. Hormonal control of vitellogenesis in penaeid shrimp. In: Flegel TW (ed) Advances in Shrimp Biotechnology. National Center for Genetic Engineering and Biotechnology, Bangkok. p. 29-32. 